УДК 821.161.2:82-94:81’42

DOI https://doi.org/10.32447/2663-340X-2019-6-31

\title{
ЩОДЕННИКИ ОЛЕКСИ ІЗАРСЬКОГО: ТЕМИ І МОТИВИ
}

\author{
Руднянин Оксана Ігорівна \\ аспірант кафедри української літератури \\ Прикарпатського національного університету імені Василя Стефаника \\ вул. Шевченка, 57, Івано-Франківськ, Украӥна
}

\begin{abstract}
Мемуарна література письменників украӥнської діаспори ХХ століття є цінним джерелом для вивчення історії української літератури, яка представлена численними творами українських емігрантів. Повоєнний період привертає особливу увагу дослідників. Нова атмосфера відкритості та вільної дискусії спонукала активний розвиток української літератури за кордоном, появі нових творчих сил покоління Другої світової війни, літературні твори яких навіяні темами і мотивами власних переживань і вражень воєнних та повоєнних років.

У статті досліджено «Щоденники» Олекси Ізарського - українського письменника-емігранта, літературознавия, критика, перекладача, представника покоління Другої світової війни, які відображають напружену інтелектуальну працю автора, щчо тривала кілька десятиліть, $i$ без якої майже неможливо відтворити життя та діяльність письменника. У дослідженні особливу увагу приділено аналізу тем та мотивів написаного автором тексту, розкрито жанрову специфіку щьоденників, визначено його синтетичну природу.

У результаті проведеного аналізу виявлено різноманітність тематики щуоденників Олекси Ізарського. Однією із провідних тем є любов до Батьківщчни, патріотизм, зв'язок людини зі своєю землею та народом. Ще однією головною темою є літературна творчість автора, а саме із записів дізнаємось про розвиток творчості письменника - це опис планів щзоо написання творів, роздуми щзоо сюжету, поетапність писання, його нескінченне читання українських та світових творів. С відгуки з листів письменників і друкованих рецензій, нотатки про зустрічі, розмови із сучасниками тощо. Письменник замислюється над космічними темами - безкінцевістю світу, проминальністю особистого. Особливу увагу автор звертає на тему смерті, трагічну долю рідних та знайомих. Переважають також й мотиви самотності, невагомості, смерті, надмотивом яких є сум та страх. Синтетична природа щоденників проявляється у поєднанні різножанрових елементів публіцистики та художнього стилю. Щоденники Олекси Ізарського відтворюють й образ самого письменника - трудолюбивої людини з високими інтелектуальними, духовними та людськими цінностями.
\end{abstract}

Ключові слова: мемуарна література, щуоенники, теми, мотиви, жанрова специфіка, синтетична природа щуоденників.

Постановка проблеми в загальному вигляді та обгрунтування іiі актуальності. Мемуарна література має велике значення для історії. Навіть у найпримітивнішому вигляді - у формі коротких записів, мемуаристика є джерелом для пізнання доби, подій, людей, побуту у суб’єктивному відтворенні авторів мемуарної літератури.

Особливої актуальності набула мемуарна література письменників української діаспори XX століття, оскільки на перші повоєнні роки припадає небувалий спалах українського літературного життя за кордоном. Цей спалах виявився у створенні письменницьких організацій, у виході безлічі книг і журналів, у влаштовуванні літературних вечорів, лекцій, дискусій, а також у появі нових творчих сил - покоління Другої світової війни. У поезії й прозі цього покоління домінують теми й мотиви, зачерпнуті із власних переживань і вражень воєнних років. Такими ж враженнями навіяна мемуарна література письменників-емігрантів, яка потребує детального вивчення як одного 3 найважливіших джерел дослідження історико-літературного процесу. Насамперед, це інформація про біографічні моменти в житті автора, його психологічний стан, мотиви творчості тощо.

Українська література XX століття збагатилася на жанр спогадів, записок, щоденників завдяки творам таких письменників, як В. Королів-Старий, Ю. Смолич, Ю. Лавріненко, І. Кедрин, I. Кошелівець, Є. Онацький, Г. Костюк, Д. Нитченко та немало інших. До їх числа належить також письменник-романіст, літературознавець, критик, перекладач - Олекса Ізарський, а його щоденники відображають напружену інтелектуальну працю автора, яка тривала кілька десятиліть і без якої майже неможливо відтворити життя і діяльність письменника.

Аналіз останніх досліджень і публікацій. Олекса Ізарський (1919-2007) є одним із непересічних представників плеяди талановитих письменників покоління Другої світової війни, що не залишився осторонь епохального творення й духовного піднесення української літератури в еміграції, давно знаний і пошанований у діаспорі. Творча спадщина письменника досі малодосліджена на Україні, без якої панорама української літератури XX століття не є повною. Про твор- 
чість Олекси Ізарського українськими літературознавцями сказано вкрай мало, деякі аспекти творчості письменника висвітлювали свого часу дослідники творчості письменників діаспори, серед яких С. Баран, П. Ротач, І. Дзюба, Р. Доценко тощо. На думку Петра Ротача, українського літературознавця, щоденники Олекси Ізарського відтворюють не лише його усамітнене і в той же час сповнене творчого палахкотіння життя, а й образ самого письменника - людини високих інтелектуальних, духовних устремлінь, інтересів, критичної думки і любові до людей $[5,8]$. Свген Баран, український літературний критик, називає щоденники письменника «сконденсованим хронологічно-понятійним циклом життя» [2].

Формулювання мети і завдань статті. Мета статті полягає в аналізі щоденників, як форми самовираження автора, у визначенні місця і ролі щоденника в життетворчості письменника. Pеалізація поставленої мети передбачає розв'язання таких завдань, як виявлення основних тем та мотивів, що використовував автор у написанні «Щоденників», розкриття жанрової специфіки щоденника, визначення його синтетичної природи.

Виклад основного матеріалу дослідження. Олексій Григорович Мальченко (справжнє прізвище) народився 1919 року на Полтавщині. У містечку Карлівці, в колі дружньої освіченої родини минули його дитячі роки. Полтава - місто юності майбутнього письменника, тут відбувалися духовне становлення молодого інтелектуала, його прилучення до скарбниці західноєвропейської культури, перші проби пера і усвідомлення своєї приналежності до поневоленої української нації [1]. До початку Другої світової війни Олекса Ізарський навчався в Київському університеті і мав незаперечну перспективу стати вченим-літературознавцем високого класу. Війна змінила обставини, і він з батьками опинився в еміграції, спершу в таборах, а згодом на вільному поселенні у США $[5,7]$. Усі художні твори, а саме цикл романів, що склали восьмитомну родинну хроніку українських інтелігентів Лисенків, а також і щоденники були написані у Клівленді, штат Огайо, де він жив усамітнено разом із братом та матір'ю. Намір опублікувати щоденники виник ще в 70-і роки. Тоді ж він почав переглядати їх і робити так звані «висмики», групуючи їх за десятиріччями, які назвав «лунами». Підготовлені до друку «висмики» 3 щоденників, тобто відбір того, що автор вважав найбільш цікавим і цінним, склали близько тисячі сторінок машинопису $[5,7]$. Фрагменти публікувалися в деяких виданнях діаспори, а в Україні вперше видано у 2006 році в Полтаві під авторською назвою ««Висмики» 3 щоденників 1940-1980 років». У щоденниках Олекси Григоровича неодноразово зустрічаємо коментарі автора про свої ж нотатки. Зокрема, він пише: «У моєму щцоденникові - ряма мого життя й історія мойх книжок. Сторонній людині тут немає поживи. Мій щоденник - ие тільки матеріал - як зву- чить ие! - матеріал для моєї біографії(!). Вона дуже потрібна людям!» [5, 282]. Стає зрозуміло, що письменник опрацьовував свої записи, залишаючи на його думку найважливіше, адже він вважав неправильним втомлювати читача непотрібною інформацією: «Щоденник мусить розквітати в пусті дні. Це значить: у деталізуванні, а не в «сповіді» подій і почувань» [5, 23]; « «Високі» щцоденники мало ціккаві, загальні. Зваба щџоденників у дрібнииях, деталях. Дрібниия - як вушко голки, крізь котре продівається нитка розумних розважань» $[5,241]$.

Незважаючи на його німецький псевдонім, який Олекса Ізарський узяв від назви річки Iзар, на березі якої письменник жив у 40-х роках в Мюнхені, доки не виїхав за океан, любов до Полтави, рідного міста свого дитинства, до батьківщини, залишилась на все життя. Тема батьківщини та образ Полтави, а загалом й України, займає значне місце як у повістях і романах другої частини родинної серії, так і в щоденникових записах: «Увечорі мерещилося щось рідне: сніг $i$ тьмяний відсвіт у вікнах маленьких будинків... Понад парканами шумлять полозки саней: жодних кордонів. Так бувало в дитинстві на Укра$\ddot{i н} i »[5,22]$. Мотив світлого дитинства періодично виринає поміж інших рядків. Стає зрозумілим, що автор сумував за рідним краєм: «... - а мені ввижасться Полтава. Найчастіме пригадую Стрітенську: іду до Йоганни Олександрівни, іду до Зої Яківни... Ранки пригадуються, пообіддя, вечори й ночі. Батьківщина» [5, 207]; «Сідання дня нагадує Полтаву і дитинство...» [5, 297]. Хвилювався автор $i$ за долю Украӥни: «Найбільший мій страх - за Украӥну. Це - найболючіме» [5, 312]; «На думиі, цілком невільно, украӥнська Украӥна» [5, 129].

Олекса Ізарський любив свою рідну українську мову та слідкував за її поширенням, за розвитком української літератури, боявся русифікації: «Життя на чужині: дивують раптом слова рідної мови! Своїм «чужорідним» звучанням!» $[5,32]$; " ... - лист Нитченка. Його дочка повернулася України: зусилення русифікаџії навіть на Західній Україні» [5, 327]. Коли трапляються події, які свідчать про занепад українського, смутку письменника немає меж: «Невільно думаю: «А ми вимираємо..» не тільки на емігращії. На Україні» $[5,201]$; «Логікою і правдою для мене є українська національність Русі або - у всякому разі - приналежність Київської історії до Украӥни виключно. Наша історія починається там, де й Англія, а Росії там, де США. - Росія організм вторинний, а Украӥна-матірний» $[5,36]$.

Серед записів $\epsilon$ й багато фактів, які свідчать про мотиви політичного характеру. $С$ згадки про вбивство Кенеді, про зняття 3 посади Хрущова, про смерть Черненка, запис про Чорнобильську катастрофу: 23.10.62. «Увечері грозова промова президента Кенннеді. Проголошено блокаду Куби: розгорнеться війна з Росією?!» [5, 43]; 26.11.63. 
«Забито президента Кеннеді. В Тексасі... Убивия Л. Освальд, що два роки прожив у Росії, його дружина москвичка. Учора відбувся похорон» [5, 52]; 13.05.80. «Несподіваний день: замах на життя Папи Римського. Новина прийшла опівдні, але скаламутила пообіддя й вечір» [5, 292].

Але помітно, що важливішим для письменника було не політичне життя, а літературне. Із щоденників дізнаємося про початки літературної творчості автора, генезу творів, літературного середовища, живих письменників того часу, накреслених короткими рисами портретів. Літературна тема $\epsilon$ домінуючою у щоденниках, а також мотиви написання книг, роботи над книгами, творчих намірів: "Думаю, що треба писати не про Юнгера, Кароссу чи Кафку, а «Віктора $i$ Лялю». - Чудо чудесне» $[5,16]$. Олекса Ізарський нотував відомості про свій творчий процес - від задуму і до того часу, коли книжка виходить у світ: "По обіді відиукав старий машинопис «Віктора $i$ Лялі» і почав їх перепрацьовувати. На душі засвітилася радість: діло! Та ще подумки мушу повернутися до Полтави! Хоч «боюся всього». Та иее «страх Божий»! - Думаю про нову книжкуяк про букет» [5, 50]; «Виринув плян розпочати «Київ» [5, 92]; «Мою серію книжок про Віктора задумую довести до десяти» $[5,116]$. Олекса Григорович цілі дні просиджував за своїм робочим столом, намагаючись написати так, щоб було цікаво українському читачеві слідкувати за розвитком подій у його романах: «Перші абзачи нового романа: «Чудо в Мисловииях». Достатня густота тексту, але малий доборок за день. Щоправда: такий ритм мого писання. Такий непорушний. Вода над берегом книжски мусить наскрізь промерзнути. Писати треба помалу: накопичення матеріалу автоматично породжує верхоглядство й задоволення вдалим слівием, натяком і позірною удалістю. Треба зразу розвивати текст, зразу його скорочувати, - залишати його в спокої циілком готовим» $[5,63]$. Проте, його рука не встигала за день записувати усе те, що було в уяві письменника, адже Олекса Григорович продовження своїх уже написаних творів вбачав ще й уві сні: «Не міг заснути: марилися сиени 3 «Києва» [5, 93]; «Пишу, виписую. I знаю: ие майже надлюдське щастя. Виходить книга. Ще далеко до кіния, проте вже над свідомістю пролітають прикінцеві розділи й сиени. На вибір» [5, 125].

Творчі досягнення письменника не залишились поза увагою відомих критиків. Вони намагалися визначити особливості прози Олекси Ізарського, вдавались до порівнянь. Деякі коментарі Олекса Ізарський нотував у щодиннику. Зокрема, із листа Ю. Стефаник до О. Ізарського: «Сьогодні Ви, на мою скромну думку, найкращий стиліст в украӥнській критиці. Остаюсь з глибокою до вас пошаною, Юрій Стефаник» [5, 31]; «I. Комелівець пише про щзойно прочитаний «Ранок»: отже повість - ие «колосальний успіх, стилем $i$ манірою ие в нас річ безпрецедентна. Від Вас (зверніть увагу як ие звучить) бере свій початок украӥнська прустіянська проза». Далі - справедлива заввага, що цю річ широкий читач просто не зрозуміє: ні афектації, ні інтриги, ні надзвичайних подій. А все це саме й робить «Ваш стиль монолітно витриманим і чистим, як сльоза, суто Вашим, щуо не дозволяє порівняння ні з ким іншим... будете літературним аристократом». А щео за синтакса!» [5, с.50]. Але не усі відгуки були позитивні, на що Олекса Ізарський реагує стримано та вдячно: «I. Коровицький написав про уривок з «Ранку» в УЛГ. Застерігає: надмір не окреслених висловів (десь, тільки, здається). Добре почути критику від людини начитаної, тонкої й доброзичливої» $[5,37]$. Про «Ранок» та про творчість Олекси Ізарського пише у листі В. Старицький: «Однак мушу Тебе запевнити, попередньо варіанти знаючи, - воно («Ранок») знайде своє місие в українській літературі, хоч і не найвище, та значно пізнавальне. Проте, великого розмаху Тобі неможливо досягнути тому лише, щзо Ти проходиш життя боягузливо, хильцем, окрайками, - глибинно його так $і$ не побачивши, не потрапивщиніколив його справжнійвир...» [5,51].

Крізь усі записи у щоденниках спостерігаємо тісний зв'язок письменника із відомими літераторами, діячами культури та просто друзями і знайомими, 3 якими він підтримував стосунки шляхом листування. Тема дружби не чітко виражена у щоденниках письменника, але поміж нотатками можна осмислити вагомість для Олекси Ізарського того листування, товаришування із знайомими колегами. Серед його численних кореспондентів відомі літератори і вчені - Улас Самчук, Григорій Костюк, Юрій Шевельов, Михайло Орест, Петро Одарченко, Дмитро Нитченко, Ігор Качуровський та інші. Особливу увагу він приділяв листам від подруги Зенти, які називав наймилішими. Із записів зрозуміло, що його німецька знайома Зента займала особливе місце у його житті, але це можна прочитати тільки поміж рядками, оскільки тема любові мало виражена, зате безумовно присутня: «Лист від Зенти: вона живе зі мною з дня на день. Тільки в Мюнхені» [5, 163]. Олекса Ізарський жодного разу не пише про свої романтичні хвилювання, наміри, мрії, тільки інколи декількома словами висловлює свої почуття від читання iї листів: «Преважливий лист, власне, два листи від Зенти. Такі листи не дано одержати двічі в житті нікому! Така ие доброта, вірність $i$ посвята» $[5,53]$. Зате відчувається сильна біль, що пройшла крізь його серце, коли померла Зента: «Померла Зента! - 21.2. о 22.30. А 20.2. у неї була моя сестра Марія й передала їй мій пакуночок. Вона тридиять років сяяла над мойм життям. Написав листа Марії, обливаючись слізьми. Тягота в грудях. Поранена свідомість» $[5,276]$. Тривожно йому й за матір, а ії хвороба та смерть стають для нього великим потрясінням: «3 8-го червня моє життя в глибокій тіні. В траурі. - Мама тепер невиліковно хвора...» 
[5, 345]; «Мама ледве жива, страждає. Задихається» [5, 347]; «Два тижні тому, 14.1, у четвер, о восьмій год. ранку, померла наша мама. Спроба не вдалася: не можу писати» [5, 347]. Смерть мами вплинула i на його відчуття самотності.

Туга за Батьківщиною та тема самотності пронизує усю книгу: «За пів години Новий Рік, значить...За останній рік я став сам собі важчим, як Крилов... Тільки щчо байок «не сочиняю». ... Душа за рік амортизувалась. Пустує моя робоча кімната: радію, як зайду до неї на пів години. Вискочив з колії. I настрій «мерзлятина», бо самота...» $[5,27]$. Олекса Ізарський усвідомлює, що сам собі обрав самотнє життя, повністю поринувши тільки у творчу діяльність: «Ясно $\check{u}$ інше: писати, творити $i$, значить, себе індивідуалізувати, вирізняти й...осамочувати» [5, 78]. Не вистачає йому реальних друзів, людей, що були 6 поруч. 3 роками їх відсутність все більше його пригнічує: "Страшно, що живу без друзів, без родичів, без людей. Живу неймовірно, як у романі. Написати б мені сім томів «Самоти»» [5, 105]. Шкода йому себе, що в самотності минає життя: «Жаль, щео життя минає в самоті» [5, 157]; «Почуваю себе на безлюдному острові. На подібних островах пройшло моє життя» $[5,265]$; «Після розмови я відчув тугу за своїми людьми. Стало страшно, що я живу так самотньо» $[5,305]$. Починаючи із записів кінця 70 -х років XX століття, все частіше з'являється мотив власної смерті: "Страшно жити, пам'ятаючи про смерть. Затемнення свідомости» $[5,157]$; «Свідомість, що кінчається життя. Життя було, доки не переслідувала думка про смерть» $[5,312]$; «Учора був день народження Бориса: 65. Жити стає страшно. Лякає смерть та самота» $[5,348]$.

Письменник замислюється над космічними темами - безкінцевістю світу, проминальністю особистого та довічністю загального. Його вражають «незмінність змін», «непереможність людської жорстокості», численні недуги сучасної культури, трагічна доля письменників. Тема смерті займає особливе місце у щоденниках Олекси Ізарського. Смерть відомих людей його емоційно хвилює, посилює його самотній та пригнічений стан: «Увечері поӥхав до бібліотеки. 3 годину проглядав журнали. Наприкінці зиркнув до «News Week»...i бачу: помер Г. Гессе. На 84 роиі життя. Серие. - ... «Прапор» у душі стрімко впав до середини илянги» $[5,43]$. Важко йому сприйняти смерть колег, 3 якими він довший час вів листування, з якими був знайомий та які були частиною його творчого життя: «...Почув, щчо помер Михайло Костьович Орест! А я вчора послав йому листа, подяку за книжку...Тільки не це! Тільки не він!.. Та його вже поховано в Мюнхені на Вальдфрідгофі. Вже не прийде від нього каліграфічний лист, не знайде мене, де б я не був» [5, 47]; «3 думки не сходить - i так печалить, так в'ялить образ Юрія В. Стефаника. Немає серед живих!.. А його листи залишилися.
Й живі такі...» $[5,326]$. Вічною пам'яттю стали для Олекси Ізарського письменники-емігранти: «...nомер Ф.А. Степун ... Пам'ять про нього надзвичайно жива, сильна. Таким був він - надзвичайної краси дуб. Кріслатий, багатий, вибагливий. Вічність знову збагатилася, погасла - сучасність» $[5,70] ;$ " 29 грудня я довідався про смерть П. Волиняка: ще одна сторінка емігрантської літератури дописана. Обірвано ще одну нитку» $[5,139]$ та інші.

Олекса Григорович записував усе вагоме, щоб засвідчити події свого історичного та літературного буття. Однак, він піддається сумнівам бути коли-небудь прочитаним на Батьківщині: «Переклав уривок з «Мальте» Рільке, «Історії з зеленої книги». - А коли б переклав иілий роман, - кому потрібно?! - Почуття, що моє життя на «похилій площині» [5, 25]; «Я пишу про листування Ролляна з Гессе. Мучуся при тому: навіщзо? Для кого?» $[5,30]$. Смуток переповнював його, коли він усвідомлював байдужість читачів до української літератури, зокрема й до своїх праць: «Пиму «В. і Л.», хоч почування мої гіркі: непотрібність моїх речей, моєї праиіџ [5, 53]; «Доводиться усвідомити істину про непотрібність мого писання. Йому ніхто не надає жодного значення...Так виринає проблема складніша, ніж знає про ие розум: Гоголь, Короленко й Україна, u Росія» $[5,75]$. Слідкував Олекса Ізарський за поширенням не тільки своїх творів, але й праць своїх колег: «Вразив факт: Ол. Воропай видав свій «Англійський щоденник» накладом у 50 пр.! А ие свідчить, що в нас немає вже не тільки читача, а й друзів! Боляче!» [5, 166]. Помітно, що надмотивом для Олекси Ізарського $є$ жаль та сум. Однак, Олекса Григорович та інші письменникиемігранти продовжують творити без читача, сподіваючись бути коли-небудь поцінованими, але чи правильно це - автор сумнівається: «Взагалі, писання в наших умовах, без читача, без відгуку, це щось геніальне або недоумкувате!» [5, 211].

Тематика щоденників Олекси Ізарського не обмежується ностальгічними мотивами. $€$ в ній багато філософських роздумів, $\epsilon$ захоплення від прочитаної світової літератури. Знайомство 3 історичними джерелами, якими безпосередньо скористався автор допомагає глибше проникнути в зміст художнього твору, пояснити вплив історичного матеріалу на формування соціальнополітичних та історичних поглядів митця, зрозуміти генезу образної системи його творів. Неможливо не звернути уваги на захоплення Олекси Ізарського видатними світовими письменниками такими, як Рільке, Томас Манн, Гессе та іншими, творчість яких стала прикладом та пізнавальним джерелом для написання творів письменника, зокрема мемуарних. Про них він пише: «За час хвороби прочитав том листів Т. Манна, на жаль, видано ще тільки перший з трьох. Так «плястично» не читалося мені давно. ...Отже: T. Манн від 1889 до року 1936. T.М. людина, прия- 
тель, батько, читач. 422 листи» [5, 41]. У працях відомих авторів Олекса Ізарський знаходить нові мотиви для своєї творчості: «Читаю надзвичайну книгу - Т. Манн описує історію написання свого романа «Др. Фавстус». В ній те, що ніхто не розповість «свойми словами». Так дбайливо розкладено матеріал! Здається, щุо книгу написано... для мене! А кличе вона до прачі, до підпорядкування їй усього життя...» [5, 42]; “Читаю Г. Гессе: "Деміян». Чар його письма, його особи, його атмосфери» $[5,50]$.

Багато читав Олекса Григорович іншомовної літератури, особливо любив щоденники відомих світових письменників, аналізував їх, робив із них багато виписок. Зокрема, описує свої враження про щоденники Г. Додерера: «Додерер уникає щоденника як особистої хроніки. Виповнює сторінки своїх записників теорією, філософією. А мені иікаві «особисті хроніки». Деталі з життя авторів. Мене иікавить «оранка» підготовка трунту під літературний посів» [5, 68]. Натомість корисними та цікавими для себе вважає щоденники С. Фіша та В. Гавзенштайна: «Сiв $i$ дочитав Фіша: його «Щоденник» - потік по коліна, навіть без ям. ... I все ж: у Фіша набралось багато тонких спостережень. Одинадиять з них я виписав. Вони, часом, прояснюють навіть відоме. Як от: "Час не змінює нас. Час нас тільки розвиває»... Або його думка такого пляну: ми і є частково такими, як нас уявляють друзі й вороги» [5, 81]; «Читаю щуоденники Вільгельма Гавзенштайна. Багато в них захоплюючого. Важливі оцінки авторів і книг: Пруст, Лєсков, Достоєвський. Добре, трунтовно подається тут атмосфера часу й місия» [5, 114].

Висновки та перспективи подальших досліджень. Щоденники Олекси Ізарського відтворюють не лише його усамітнену творчу працю, а й образ самого письменника - трудолюбивої людини з високими інтелектуальними, духовними та людськими цінностями. Усе своє життя Олекса Ізарський присвятив літературі. Олекса Григорович писав: «...Живи буднем, бери $з$ нього сонце й тишу. Найсильніша приправа до нього - творчість, писання книг» $[5,53]$. Його «Щоденники» $€$ органічною єдністю документального, художнього та публіцистичного начал. Його синтетична природа проявляється у поєднанні різножанрових елементів публіцистики та художнього стилю. Щоденникам Олекси Григоровича притаманна відсутність єдиного сюжету. Автор пише уривчасто, стисло, використовуючи мовну свободу. Його речення короткі і з відповідно дібраними словами. Мова щоденників проста, доступна для читача, вільна від теорій, написана від серця: «Щодо мене: я йду просто, крокую не від і не до теорій. У мене вся поетика зведена до смаку» $[5,109]$.

Щоденники Олекси Ізарського різноманітні за тематикою, але однією із провідних тем його творчості $є$ тема батьківщини, патріотизму, зв'язку людини зі своєю землею та народом. В центрі своїх щоденників автор поставив своє власне життя, свої переживання, розповів про літературне, наукове, громадсько-політичне життя своєї доби та про численних видатних українських письменників, діячів української культури, про їх трагічну долю. Із записів також дізнаємось про розвиток творчості письменника - це опис планів щодо написання творів, роздуми щодо сюжету, поетапність писання, його нескінченне читання українських та світових творів. Переважають також й мотиви самотності, невагомості, екзистенційної закинутості, непотрібності, смерті, надмотивом яких є сум та страх. У «Щоденниках» О. Ізарського знайшла відображення мало не вся доба другої хвилі української еміграції - події і життя людей, що стали політичними вигнанцями 3 України.

Минуло сто років від дня народження українського письменника-емігранта Олекси Ізарського, а його ім'я й досі мало відоме на Україні. Рідне місто пошанувало високий талант свого земляка, видавши «Висмики» 3 щоденників, а також повісті «Столицю над Ізаром», «Ранок», перевидавши роман «Полтава». Сьогодні твори Олекси Ізарського залишаються маловідомими, тому й потребують подальшого дослідження.

\section{ЛIТЕРАТУРА}

1. Анненкова А. На Вікторовій вулиці. URL: http://izarskiy.ssu-poltava.org/ranen_2.htm (дата звернення: 5.12.2019).

2. Баран Є. Щоденник клівлендського самітника. Літакиент. 2017. URL: http://litakcent.com/2007/11/28/ jevhen-baran-shhodennyk-klivlendskoho-samitnyka (дата звернення: 30.11.2019).

3. Басинский П. Мемуары - жанр сложный и благородный. Вопросы литературы. 1999. №1. С. 5-6.

4. Дзюба I. Туга за великою літературою: «Щоденники» Олекси Ізарського. Україна: культурна спадщина, наиіональна свідомість, державність. 2012. С. 282-299.

5. Ізарський О. «Висмики» 3 щоденників. 1940-1980-і роки. Полтава: Динамік, 2006. 392 с.

6. Ільків А.В. Жанр щоденника в українській літературі другої половини XX - початку XXI століть: монографія. Надвірна: ЗАТ Надвірнянська друкарня, 2010. 287 с.

7. Luckyj George S.N. Ukrainian literature in the twentieth century: A reader's guide. Toronto. University of Toronto Press, 1992. 136 pp. 


\title{
REFERENCES
}

1. Annenkova A. Na Viktotovii Vulytsi. [At Victor's Street]. URL: http://izarskiy.ssu-poltava.org/ranen_2.htm.

2. Baran Ye. Shchodennyk klivlends'koho samitnyka. [Diaries of one lonely man from Cleveland]. Litaktsent, 2017. URL: http://litakcent.com/2007/11/28/jevhen-baran-shhodennyk-klivlendskoho-samitnyka.

3. Basinskij P. Memuary - zhanr slozhnyj i blagorodnyj. [Memoir - complex and noble genre]. Voprosy literatury / P. Basinskij, 1999. № 1. S. 5-6.

4. Dziuba I. Tuha za velykoiu literaturoiu: "Shchodennyky" Oleksy Izars'koho. [Longing for great literature: "Diaries" of Oleksa Izarskyi]. Ukraina: kul turna spadshchyna, natsional'na svidomist', derzhavnist'. 2012. S. 282-299.

5. Izars'kyi O. "Vysmyky" $z$ shchodennykiv. 1940-1980-i roky. [Selected notes from diaries. 1940-1980 years]. Poltava: Dynamik, 2006. 392 s.

6. Il'kiv A.V. Zhanr shchodennyka v ukrains'kii literaturi druhoi polovyny XX - pochatku XXI stolit': monohrafiia. [Diary as a genre in Ukrainian literature of the late $20^{\text {th }}$ - early $21^{\text {st }}$ centuries: monograph] / A.V. Il'kiv. Nadvirna: ZAT Nadvirnians'ka drukarnia, 2010. $287 \mathrm{~s}$.

7. Luckyj George S.N. Ukrainian literature in the twentieth century: A reader's guide. Toronto. University of Toronto Press, 1992. $136 \mathrm{pp}$.

\section{OLEKSA IZARS'KYI'S DIARIES: THEMES AND MOTIVES}

\author{
Rudnianyn Oksana Ihorivna \\ Postgraduate Student at Department of Ukrainian Literature \\ Vasyl Stefanyk Precarpathian National University \\ 57 Shevchenko Str., Ivano-Frankivsk, Ukraine
}

\begin{abstract}
Memoir literature of the Ukrainian diaspora in the twentieth century is a valuable source of information for the study of the history of Ukrainian literature. It is represented by the numerous works of Ukrainian emigrants. The post war period attracts special attention of scientists. The new atmosphere of openness and free discussion was very stimulating for the development of Ukrainian literature abroad, for the rise of the new creative forces - World War II Generation. In poetry and prose of this generation dominate themes and motives drawn from writers'own experiences and impressions of war and postwar years.

The article studies the Diaries written by Oleksa Izars 'kyi - the Ukrainian writer-emigrant, literary critic, translator, the representative of World War II Generation. The diaries depict intense intellectual author's work, which had lasted for several decades and made the basis for the reconstruction of information about writer's life and activity. The study pays special attention to the analysis of themes and motives of diaries, reveals their genre specificity, defines their synthetic nature.

According to the results of the analysis the diaries are written by Oleksa Izars 'kyi on a wide variety of themes. One of the main topics is about his homeland, patriotism, connection to his land and nation. One more central theme is author's literary work. The notes in the diaries give us the information about the development of writer's literary process - description of plans on writing of his works, thoughts concerning the plot, stage-by-stage writing, his endless reading of Ukrainian and world literary works. The diaries contain the comments on letters of other writers, notes about meetings, conversations with contemporaries etc. Oleksa Izars 'kyi thinks over the cosmic themes - world endlessness, flow of individuality. The author pays particular attention to the topics such as death, tragic fate of relatives and acquaintances. Motives of loneliness, insignificance, death prevail in diaries, caused by the feelings of sorrow and fear. The synthetic nature of diaries reveals in connection of a variety genre features of publicistic and belletristic styles.

The Diaries written by Oleksa Izars 'kyi reproduce the image of the writer - hard-working person with high intellectual, spiritual and human values.
\end{abstract}

Key words: memoir literature, diaries, themes, motives, genre specificity, synthetic nature of diaries. 